\title{
Jurisdiction of International Court of Justice (ICJ) Over the Genocide Violations: with Special References to Rohingya Case
}

\section{Yordan Gunawan $^{1}$, Sonya Whisler Refisyanti ${ }^{2}$, Aliza Mufida ${ }^{3}$, Kukuh Derajat Takarub ${ }^{4}$, Aisah Nur ${ }^{5}$}

${ }^{1}$ Universitas Muhammadiyah Yogyakarta, Indonesia, Email: yordangunawan@umy.ac.id

${ }^{2}$ Universitas Muhammadiyah Yogyakarta, Indonesia, Email: sonya.whisler.law17@mail.umy.ac.id

${ }^{3}$ Universitas Muhammadiyah Yogyakarta, Indonesia, Email: aliza.mufida.law17@mail.umy.ac.id ${ }^{4}$ Universitas Muhammadiyah Yogyakarta, Indonesia, Email: kukuh.derajat.law17@mail.umy.ac.id

${ }^{5}$ Universitas Muhammadiyah Yogyakarta, Indonesia, Email: aisah.nur.law17@mail.umy.ac.id

\section{Article Info}

Keywords:

International Court of Justice, Jurisdiction of ICJ, Gambia, Genocide Violation, Myanmar, Rohingya.

\section{How to cite:}

Yordan Gunawan, Sonya Whisler Refisyanti, Aliza Mufida, Kukuh Derajat Takarub, Aisah Nur,

"Jurisdiction of International Court of Justice (ICJ) Over the Genocide Violations: with Special References to Rohingya Case", Fiat Justisia: Jurnal Ilmu Hukum 14, no. 4 (2020): 313-336.

DOI:

10.25041/fiatjustisia.v14no4.1900
Abstract

In 2019, the Gambia, a small country located in West Africa, sues Myanmar to the International Court of Justice (ICJ) with alleging that Myanmar has violated the Convention on the Prevention and Punishment of the Crime of Genocide 1948. The governments of Myanmar in doing the violations intended to destroy the Rohingya Muslim as a group, wholly or partly, followed by other violations such as mass murder, rape, and also damage to the villages by the fire with some people are still locked in the house and burnt inside the house. The government of Myanmar keeps doing so because, based on Burma Citizenship Law 1982, Myanmar does not recognize the existence of Rohingya as a citizen of Myanmar. It causes Rohingya as stateless. The study is normative legal research with Statute Approach and Case Approach. The study analyses the violations which are done by Myanmar to the Rohingya Ethnic in Rakhine. The result shows that the International Court of Justice has jurisdiction upon the Rohingya case under the Statute of the Court as well as the Genocide Convention. In Article 36 (1), ICJ has jurisdiction to all cases Convention as long as the states are contracting parties. Article IX of the Convention also stated that any dispute between contracting parties must be referred to ICJ. 


\section{A. Introduction}

In 1956, Myanmar ratified the Convention on the Prevention and Punishment of the Crime of Genocide 1948. Although Myanmar already ratified the Convention, Myanmar was claimed by the Gambia do a crime of genocide to Rohingya ethnic group. Rohingya are one from many ethnic groups in Myanmar, despite that because of the establishment of Myanmar's 1982 Citizenship law mentioned eight major ethnic groups which are divided into 135 subs-group ${ }^{1}$. Rohingya are not considered one of the official ethnic group mentioned in the law. Since 1982 Myanmar has been denied Rohingya citizenship, which makes the Rohingya people become stateless. ${ }^{2}$ Rohingya ethnic group lived in the Rakhine state on the western coast of Myanmar. Rohingya is the ethnic group who are most of them are Muslim who have resided in the majority of Buddhists in Myanmar.

According to the Amnesty International (AI) report, ${ }^{3}$ Since 1978, Rohingya have suffered from human rights violation committed by the military junta in Myanmar, and many have absconded to neighbouring countries such as Bangladesh. The tensions of Rohingya came to the public in May 2012 following the case of a Buddhist woman who raped and killed in Rakhine state, and three Rohingya men were blamed for being responsible. ${ }^{4}$

The Rakhine and the Rohingya both upheld the weapon against one another, leaving at least 200 dead and many other incidents after that case. ${ }^{5}$ An essential factor in the violence was a Buddhist nationalist group led by monks. ${ }^{6}$ The group of monks is recognized by it is an anti-Muslim grudge, which many consider genocidal. ${ }^{7}$ The Rabid Buddhist organizations have been at the core of inter-communal violence ever since the replication of relative democracy in $2011 .^{8}$

${ }^{1}$ Nehginpao Kipgen, “The Rohingya Crisis: The Centrality of Identity and Citizenship," Journal of Muslim Minority Affairs 39, No. 1, (2019): 61-74.

2 A. K. M. Ahsan Ullah, "Rohingya Crisis in Myanmar: Seeking Justice for the "Stateless," Journal of Contemporary Criminal Justice 32, No. 3, (2016): 285-301. https://doi.org/10.1080/13602004.2019.1575019.

3 Amnesti International, "We Are at Breaking Point-Rohingya: Persecuted in Myanmar, Neglected in Bangladesh", Research Report, Amnesty International Ltd, (2016).

${ }^{4}$ Ismail Suardi Wekke et al., "Muslim Minority in Myanmar: A Case Study of Myanmar Government and Rohingya Muslims," Walisongo: Jurnal Penelitian Social Keagamaan 25, No. 2, (2017): 303-324. https://doi.org/10.21580/ws.25.2.2317.

5 Patrick Brown, Preparations for Genocide and Crimes Against Humanity Against Rohingya Muslims in Rakhine State, Myanmar (Myanmar: Fortify Rights, 2018), 55.

${ }^{6}$ Matthew J. Walton and Susan Hayward, "Contesting Buddhist Narratives: Democratization, Nationalism, and Communal Violence in Myanmar", Research Report, East-West Center, (2014).

7 Warzone Initiative, 2015, Rohingya Briefing Report, available at https://www.equalrightstrust.org/ertdocumentbank/Rohingya\%20Briefing\%20Report.pdf accessed on Friday, December 20, 2019, at 17.03.

${ }^{8}$ Azeem Ibrahim, The Rohingyas: Inside Myanmar's Genocide (United Kingdom: C. Hurst \& Co. Publisher Ltd., 2018), 20. 
The government policy of Myanmar that was discriminative led to the humanitarian tragedy against the Rohingya Muslim minority. The Myanmar Government committed murder, or cleansing, expulsion, and seizure of Rohingya minority properties. Although the alleged crimes of genocide or massacre are still being debated, the bloody tragedy of the Rohingya minority has been classified as the most severe crime of humanity. ${ }^{9}$

In November $2019^{10}$, The Republic of Gambia instituted proceedings against the Republic of the Union of Myanmar, alleging violations of the Convention on the Prevention and Punishment of the Crime of Genocide (the "Genocide Convention") through "acts adopted, taken and condoned by the Government of Myanmar against members of the Rohingya group". Particularly in the International Court of Justice press release, Gambia claims that the Tatmadaw and security forces of Myanmar started the 'clearance operations' to the Rohingya group since October 2016. ${ }^{11}$

The genocide act which done by the Tatmadaw and security forces of Myanmar was intended to destroy the Rohingya Muslim as a group, wholly or partly, followed by other violations such as mass murder, rape, and also damage to the villages by the fire with some people are still locked in the house and burnt inside the house. From August 2017 until the Gambia submit the proceedings in November 2019, that kind of violations still continuous with the term' clearance operations' in a more enormous and broader geographical scale. ${ }^{12}$ Although the Gambia already submitted the proceedings to the International Court of Justice against Myanmar, Myanmar still denies any wrongdoing. The case has not met a conclusion, or the case does not end yet, the case had just entered the second hearing on December 12, 2019.

The topic needs to be discussed because what happens to the Rohingya ethnic is not only violence the human right but also influence many countries especially the countries which become a destination of the refugees from Rohingya and the case need to be discussed to supervise the development of the Rohingya case and supervise the course of judicial action which taken by the Gambia against Myanmar. So, what means by particular reference to the Rohingya case is the research will explain the jurisdiction of ICJ over genocide violation by giving the specific case of the Rohingya cause, which happens today. In drafting the Genocide Convention in 1948, the international community, included a submissions clause that provided for jurisdiction in the

\footnotetext{
${ }^{9}$ Ismail Suardi Wekke et al., Loc.Cit.

${ }^{10}$ International Court of Justice Press Release, 2019, Press Release No. 47, available at Tuesday https://www.icj-cij.org/files/case-related/178/178-20191111-PRE-01-00-EN.pdf accessed on December 17, 2019, at 02.22.

${ }^{11}$ Ibid.

12 International Court of Justice, 2019, International Court of Justice Application Instituting Proceedings and Request for Provisional Measures: Republic of the Gambia V. Republic of the Union of Myanmar, available at https://www.icj-cij.org/files/case-related/178/178-20191111APP-01-00-EN.pdf accessed on Friday, December 13, 2019, at 13.33.
} 
International Court of Justice (ICJ) against a state that might violate the Convention. ${ }^{13}$ The problem is what happens in Rohingya can be categories into the genocide case, and the violation of genocide, as stated in the genocide convention, is under the jurisdiction of ICJ. Besides ICJ, there is a court name International Criminal Court (ICC), and Genocide violations are categories as a criminal act. But why Gambia is suing Myanmar through ICJ? Does the ICJ have jurisdiction upon the genocide case which happens in Myanmar? That question will be answered in the research.

The type of research is normative legal research with the international law approach through the regulations and conventions related to the Rohingya. The research use statute approach would inform some regulations such as the Convention on the Prevention and Punishment of the Crime of Genocide 1948 and Myanmar Citizenship Law. The research would as well use case approach because the research aims to study the International Court of Justice decision and other regulations in practice related to the Rohingya's case. The data were analyzed systematically through the qualitative juridical approach, consistently through evaluative, where the data was taken relating to the issues to be researched. ${ }^{14}$

\section{B. Discussion}

\section{Historical of Rohingya Ethnic}

Myanmar, also known as Burma, gained its independence from Britain in 1948 and was ruled by the military junta from 1962 until it was dissolved after the election in $2010 .{ }^{15}$ Broadly speaking, Rohingya is an ethnic-patterned Muslim group that originated from northern Rakhine, the western part of Myanmar that was once called Arakan, one of the poorest regions of the country, ${ }^{16}$ are considered among the most mistreated, helpless, and burdened minorities in the world. 59.7\% of the 3.8 million populations in Rakhine are Buddhist, the other $35.6 \%$ are Rohingya Muslim, and the rest are from another ethnic or religious group. ${ }^{17}$ The Rohingya Muslims are a mixture of diverse ethnic groups, such as Arabs, Moghuls, and Bengalis. ${ }^{18}$

\footnotetext{
${ }^{13}$ John Quigley, "International Court of Justice as a Forum for Genocide Cases", Case Western Reserve University: Journal of International Law 40, No. 1, (2007): 243. https://doi.org/10.2139/ssrn.1017825.

${ }^{14}$ Johnny Ibrahim, Teori dan Metodologi Penelitian Hukum Normative, Second Edition (Malang: Bayu Media, 2006), 303.

${ }^{15}$ Ismail Suardi Wekke et al., Loc.Cit.

16 Haradhan Kumar Mohajan, "History of Rakhine State and the Origin of the Rohingya Muslims", Premier University, Chittagong, Bangladesh: The Indonesian Journal of Southeast Asian Studies, 2, No. 1, (2018): 19-46. https://doi.org/10.22146/ikat.v2i1.37391

${ }^{17}$ Ibid.

${ }^{18}$ Imtiaz Ahmed, The Plight of the Stateless Rohingyas: Responses of the State, Society \& the International Community (Dhaka: The University Press Ltd, 2010), 59.
} 
Rakhine state is located on the border with Bangladesh. ${ }^{19}$ That's why Burmese hatred and fear of "foreigners" in their midst turned against the Rohingya, whom considered as "illegal immigrants" or classified as Bangladeshi because Rohingya Muslims are alike Bangladeshi in cultural and physical characteristics. Rohingya's were targeted not only because perceived as "foreigners" but also due to the fact that Rohingya were Muslims in an overwhelmingly Buddhist country. ${ }^{20}$ In short, it can be concluded that Rohingya is the minority group in Myanmar.

Myanmar's military junta promulgated the Citizenship Law 1982 that effectively stripped the Rohingya of their citizenship. ${ }^{21}$ The impact of the law, it makes the ethnic Rohingya Muslims, classified as stateless citizens. They have been treated as illegal immigrants in Myanmar and denied the group recognition as one of the ethnic of the country, which Myanmar is the country with 135 ethnic groups. $^{22}$

The military junta strongly suspected the Rohingya people as new people coming from Bangladesh. ${ }^{23}$ Meanwhile, other tribes in Myanmar, such as Karen, Shan, Dagu, Kachin, and Mon, were given excellent treatment; even their needs were all well-organized. ${ }^{24}$ This indicates that the government of Myanmar has not paid much attention to Rohingya Muslims because their tribe is still confusing, rather than other tribes that have been organized by the government of Myanmar. ${ }^{25}$

According to some historians, ${ }^{26}$ Rohingya does not belong to Myanmar. Meanwhile, others believe Rohingya has lived there for hundreds of years. The polemics surrounding Rohingya's origins are the result of a political struggle, a misguided notion of national identity, intolerance, and discrimination. The truth is that in general, Rohingya Muslims have lived in western Myanmar before the British occupation of the province. ${ }^{27}$

Some of the factors that are historical, legal, and socio-economic can explain why the Rohingya Muslim minority has no citizenship status and

\footnotetext{
${ }^{19}$ Haradhan Kumar Mohajan, Loc.Cit.

${ }^{20}$ Emilie Biver, "Religious nationalism: Myanmar and the role of Buddhism in anti-Muslim narratives", Lund University (Master of Science and Department of Political Science), (2014).

${ }^{21}$ Ghazala Parveen, "Recent Trends in South Asian Politics: Rohingya Crisis to Nrc and Citizenship Bill in India", Kazi Nazrul University, Asansol: International Journal of Innovative Research and Advanced Studies (IJIRAS) 5, No. 10, (2018).

${ }^{22}$ Amnesty International, 2004, Myanmar, The Rohingya Minority: Fundamental Rights Denied, available at https://www.amnesty.org/download/Documents/92000/asa160052004en.pdf accessed on Thursday, December 19, 2019, at 23.04.

${ }^{23}$ Simon Knuters, "Political Buddhism and the Exclusion of Rohingya in Myanmar", Uppsala Universitet (Department of Theology), (2018).

${ }^{24}$ Imtiaz Ahmed, Op.Cit., 89.

${ }^{25}$ Simon Knuters, Loc.Cit.

${ }^{26}$ Ismail Suardi Wekke et al., Loc.Cit.

${ }^{27}$ T. V. Paul and John A. Hall, International Order and the Future of World Politics (Cambridge: Cambridge University Press, 1999), 133.
} 
become a victim of the malignancy of some of the Burmese authorities. ${ }^{28}$ Rohingyas are originally immigrants who came to Burma a few centuries ago. ${ }^{29}$ Some argue that Rohingyas originated in Arabic Rahama (affectionate) and originated from the sultanate in Bengal. ${ }^{30}$ From posture and language, Rohingya tend to have a standard physical and linguistic look with the Bangladesh people. ${ }^{31}$ Their language use is related to the Chitagonian language used by most people in the southern border region of Bangladesh ${ }^{32}$. Geographically, the Arakan region (Rakhine) most of them live in the borders between Bangladesh and Arakan of West Burma (Myanmar). ${ }^{33}$

Recent violence in Myanmar's northern Rakhine state has displaced around 700,000 Rohingyas to neighbouring Bangladesh and several hundred thousand within Myanmar. ${ }^{34}$ The violations which are done by the Tatmadaw and other security force was started from October 2016 and August 2017, with the actions in so-called 'clearance operations' to Rohingya Muslim, a distinct Muslim ethnic minority, in Rakhine State, Myanmar. ${ }^{35}$ The violations which started in the second phase, August 2017, were categorized as the most severe and brutal violations and also against the human rights in the massive number of the victim $^{36}$. Survivors report indiscriminate killings, rape and sexual violence, arbitrary detention, torture, beatings, and forced displacement. ${ }^{37}$

Also, in August 2017, Arakan Rohingya Salvation Army (ARSA) members and local Rohingya supporters reportedly attacked thirty security facilities, including border outposts and one military base, killing over a dozen Burmese Security Personnel. ${ }^{38}$ ARSA fights against the Tatmadaw. ${ }^{39}$ In Independence Day of Myanmar, January 4, 2019, the Arakan Army launched coordinated

\footnotetext{
${ }^{28}$ Warzone Initiative, Loc.Cit.

${ }^{29}$ Samuel C. Y. Ku and Kristina Kironska, Migration in East and Southeast Asia, Singapore: World Scientific Publishing Co. Pte. Ltd (2017), p. 221.

${ }^{30}$ M.A. Tahir Ba Tha, A Short History of Rohingya and Kaman's of Burma (Burmese: Institute of Arakan Studies, 1963), 17.

${ }^{31}$ Ismail Suardi Wekke et al., Loc.Cit.

32 Braj B. Kachru, et al., Language in Southeast Asia (Cambridge: Cambridge University Press, 2008), 37.

33 Kawse Ahmed and Helal Mohiuddin, The Rohingya Crisis: Analyses, Responses, and Peacebuilding Avenues (London: The Rowman \& Littlefield Publishing Group, Inc, 2020), xviii.

34 UNHCR, 2019, Rohingya Emergency, available at https://www.unhcr.org/rohingyaemergency.html accessed on Monday, December 23, 2019, at 09.18.

35 Zoltan Barany, "The Rohingya Predicament: Why Myanmar's Army Gets Away with Ethnic Cleansing", Istitutio Affari Internazional, (2019).

${ }^{36}$ John P. J. Dussich, "The Ongoing Genocidal Crisis of the Rohingya Minority in Myanmar", University Delhi: Journal of Victimology and Victim Justice 1, No. 1, (2018). https://doi.org/10.1177/2516606918764998.

${ }^{37}$ Zoltan Barany, Loc.Cit.

${ }^{38}$ Ghazala Parveen, Loc.Cit.

39 Aneela Aziz and Anila Kamal, "Final Proceedings of ICHRCP 2018", Conference Paper, Quaid: Azam University, (2019).
} 
attacks on four border police outposts in northern Buthidaung Township, Rakhine State, and killed 13 police officers. ${ }^{40}$

\section{ICJ: Role and Jurisdiction}

Established in 1945, the International Court of Justice, which seat in The Hague, is one of the six principal organs of the United Nations. ICJ is still the most relevant International Tribunal. ${ }^{41}$ The ICJ"s has two principal roles. First, the court can settle the international legal disputes between states (contentious jurisdiction), or in other words, is to settle peacefully international or bilateral disputes between States submitted to it within the confines of its jurisdiction and in accordance with international law. ${ }^{42}$ Second, it provides advisory opinions on questions of international law to specific UN organs and specialized agencies (advisory jurisdiction). ${ }^{43}$ The ICJ does not hear contentious cases brought by individuals or groups against a state - only states can bring cases against other states. ${ }^{44}$ Furthermore, for the role of ICJ, under Article 65 of the ICJ Statute, the international organization may ask the ICJ for an advisory opinion, 'on any legal question'. Under the Article 96 UN Charter, the Security Council and the General Assembly are empowered to do so, and other organizations may do so as well, provided they are authorized to do so by the General Assembly.

In general, jurisdiction is the power of a State 'to make its law applicable to the activities, relations, or status of persons, or the interests of persons in things, whether by legislation, by executive act or order, by administrative rule or regulation, or by determination by a court ${ }^{45}$ In the research, what mean by jurisdiction by the researchers which related to the issue is a term that refers to whether a court has the power to hear a given case. Jurisdiction is relevant because it limits the power of a court to hear certain cases. If courts did not exercise appropriate jurisdiction, every court could conceivably hear every case brought to them, which would lead to confusing and contradictory results. The general jurisdiction of ICJ: it can, in principle, adjudicate claims on all sorts of topics, ranging from maritime delimitation to violation of the law of armed

\footnotetext{
${ }^{40}$ Md Ziaur Rahman et al., "Rohingya Crisis: Identity of Rohingya Muslim in Myanmar", International Community Science Association: International Research Journal of Social Science 7, No. 12, (2018): 13.

${ }^{41}$ Jan Klabbers, International Law 2nd Edition (Cambridge: Cambridge University Press, 2017), 158.

42 Martin Dixon et al., Cases and Materials on International Law (New York: Oxford University Press, 2011), 634.

${ }^{43}$ Ibid.

${ }^{44}$ International Commission of Jurist, 2014, ICJ Welcomes Chance to Review ASEAN Human Rights Commission's TOR, available at https://www.icj.org/icj-welcomes-chance-to-reviewasean-human-rights-commissions-tor/ accessed on Tuesday, December 24, 2019, at 22.21.

45 John B. Houck, "Restatement of the Foreign Relations Law of the United States (Revised): Issues and Resolutions", The International Lawyer, 20 (4), (1986), pp. 1361-1390.
} 
conflict, and ranging from environmental claims to claims involving financial issues. ${ }^{46}$ The Jurisdictions of the Court are listed in Article 36 of the ICJ Statute, the jurisdiction of the court comprises all cases which the parties refer to it all matters specially provided for in the Charter of the United Nations of in the treaties and conventions in force. ${ }^{47}$ By virtue of Article 92 of the Charter in 'principal judicial organ of the United Nations' and also Judge Lachs, the ICJ is the guardian of legality for the international community as a whole, both within and without the United Nations. ${ }^{48}$

The court had noted that although the political aspects maybe arise in any legal dispute brought before it, the court only had jurisdiction in establishing if there was a question on legal dispute 'in the sense of a dispute capable of being settle by the application of principle and rules of international law'. ${ }^{49}$ The fact that other elements are present cannot detract from the characterization of a dispute as a legal dispute. ${ }^{50}$

The court has also referred to the assessment of the legality of the possible action of the states with regard to international legal obligations as an 'essentially judicial task'. ${ }^{51}$ Accordingly, 'the task of the court must be to respond, on the basis of international law, to the particular legal dispute brought before it. As it interprets and applies the law, it will be mindful of context, but its task cannot go beyond that'. ${ }^{52}$

\section{The Role and Jurisdiction of ICJ Over Rohingya}

The Convention on the Prevention and Punishment of the Crime of Genocide 1948 ratified by Myanmar in $1956^{53}$. Article 2 of the Genocide Convention stated about what means by genocide ${ }^{54}$. From that definition of

\footnotetext{
${ }^{46}$ Jan Klabbers, Op.Cit., 158.

${ }^{47}$ Susan Park, International Organisations, and Global Problems: Theories and Explanations (Cambridge: Cambridge University Press, 2018), 37.

${ }^{48}$ Malcolm N. Shaw, International Law (Cambridge: Cambridge University Press, 2017), 808.

${ }^{49}$ Bartram S. Brown, "Primacy or Complementarity: Reconciling the Jurisdiction of National Courts and International Criminal Tribunals," The Yale Journal of International Law 23, No. 383 , (1998).

${ }^{50}$ Philippe Sands and Pierre Klein, Bowett's Law of International Institutions (England: Thomson Reuters Ltd, 2009), 38-39.

${ }^{51}$ Advisory opinion of the International Court of Justice, Legal Consequences of the Construction of a Wall in the Occupied Palestinian Territory, available at https://www.un.org/unispal/document/auto-insert-178825/ accessed on Tuesday, December 24, 2019 , at 13.55 .

${ }^{52}$ Malcolm N. Shaw, Op.Cit, 809.

${ }^{53}$ United Nations Treaty Collection, Chapter IV: Human Rights, Sub Chapter: Convention On the Prevention and Punishment of the Crime of Genocide, available at https://treaties.un.org/Pages/ViewDetails.aspx?src=TREATY\&mtdsg_no=IV-

$1 \&$ chapter $=4 \&$ clang=_en accessed on Friday, December 20, 2019, at 22.16.

${ }^{54}$ United Nations Treaty Series, No. 1021 Convention On the Prevention and Punishment of the Crime of Genocide, adopted by The General Assembly of the United Nations On December 9
} 
genocide, the Genocide Convention 1948 defines genocide as a number of actions, including killing or causing severe physical or mental damage. However, it will define as genocide if there are an "intent to destroy", in whole or in part, national, ethnic, racial, or religious groups. Indeed, the existence of this particular intention, "intent to destroy", that distinguishes genocide from other heinous crimes. The particular intention is fundamental because there is a difficulty in proving genocidal intentions in the courtroom. In the absence of direct conclusive evidence, the ICJ will deduce genocidal intentions from certain circumstances, such as the pattern of actions carried out against targeted group members ${ }^{55}$. That is only if the situation indicates the existence of that intention.

On November 11, 2019, Gambia submitted institutes proceedings against Myanmar. It asked ICJ to indicate provisional measures concerning the genocide that cause damage for Rohingya Muslims ${ }^{56}$. the Gambia stated that Myanmar had committed "real" violations of the Genocide Convention through its military actions, and continued to do so. These actions, according to testimony in the trial, included "extrajudicial killings, rape, or other forms of sexual violence, arson, and destruction of livestock, which are calculated to cause damage to the Rohingya group in whole or in part". ${ }^{57}$ Which means, Myanmar has violated the Genocide Convention 1948.

The way how the government of Myanmar does the genocide is through the Military of Myanmar (as known as 'The Tatmadaw') and other Myanmar security forces, they have started the genocide violation (clearance operation the term that uses by Myanmar) to the Rohingya people. The case of genocide to Rohingya people is happening in two-phase..$^{58}$ The first phase was started from October 2016 until the end of January 2017. The second phase started in August 2017 until November 2019. Around 3,000 people were killed on the phase which happens between August 25, 2017, until September 11, 2017 ${ }^{59}$. On September 22, 2017, the villages of Rohingya were being burned from the point of view of the satellite images. ${ }^{60}$ As a result of the event, around 700,000

1948, available at https://treaties.un.org/doc/publication/unts/volume\%2078/volume-78-i-1021english.pdf accessed on Saturday, December 21, 2019, at 09.12.

${ }^{55}$ Claus Kreb, "The International Court of Justice and the Elements of the Crime of Genocide", European Journal of International Law 18, No. 4, (2007): 619-629. https://doi.org/10.1093/ejil/chm039.

56 International Court of Justice, 2019, International Court of Justice Application Instituting Proceedings and Request for Provisional Measures: Republic of the Gambia V. Republic of the Union of Myanmar, Loc.Cit.

${ }^{57}$ Ibid.

${ }^{58}$ John P. J. Dussich, Loc.Cit.

59 United States Holocaust Memorial Museum, "They Tried to Kill Us All: Atrocity Crimes against Rohingya Muslims in Rakhine State, Myanmar”, Fortify Rights: Bearing Witness Report, (2017).

${ }^{60}$ Amnesty International UK, 2017, Myanmar: 'Damning' Video and Satellite Evidence Shows New Fires in Rohingya Villages, available at https://www.amnesty.org.uk/press- 
Rohingya people were move (becoming refugees) to Bangladesh (as the neighboring country) since August 25, 2017.61 After all of this, the study estimated that around 18,000 Muslim women and girls were raped in Rohingya, around 116,000 Rohingya people were beaten, and around 36,000 Rohingya people were thrown into the fire. ${ }^{62}$

In the Myanmar, genocide trial, which began on Tuesday (10/12) at the ICJ in The Hague, Myanmar Chancellor Aung San Suu Kyi was passive and did not react much. ${ }^{63}$ The failure of the world to act on the Myanmar genocide is a "blemish in our common conscience," 64 According to the Attorney General and Gambian Justice Minister, Abubacarr Marie Tambadou, who is demanding the case. Aung San Suu Kyi only sat quietly during a report read out about the mass killings and rape and genocide of Myanmar, at the beginning of a three-day trial of alleged genocide in Myanmar in ICJ, the highest court of the United Nations. ${ }^{65}$

The decision of the ICJ will depend on the votes of the judges. If 17 judges lead the case, at least nine judges must agree on the Gambia accusations or Myanmar's defence. ${ }^{66}$ Dr Myint Zan also claims that Myanmar can easily deny the case, just like other countries that have been tried at ICJ, that ICJ does not have jurisdiction to judge Myanmar and fight at the point that Gambia is not in the right position to accuse Myanmar in ICJ ${ }^{67}$ The trial taking place at the ICJ will not decide whether the Myanmar government is responsible for genocide charges, but the government to provide clarification on the current status. ${ }^{68}$

According to Myint Zan, if an official explanation regarding Myanmar is not accepted, it will be Myanmar's victory in the legal battle. If the case is accepted, then it will take at least three years if the ICJ decides to continue the

releases/myanmar-damning-video-and-satellite-evidence-shows-new-fires-rohingya-villages accessed on Monday, December 23, 2019, at 10.36.

${ }^{61} \mathrm{Ibid}$.

62 Ghazala Parveen, Loc.Cit.

${ }^{63}$ Public Sitting of International Court of Justice, 2019, Public Sitting: In the case concerning Application of the Convention on the Prevention and Punishment of the Crime of Genocide (The Gambia v. Myanmar), available at https://www.icj-cij.org/files/case-related/178/178-20191211ORA-01-00-BI.pdf accessed on Wednesday, December 11, 2019, at 10.57.

${ }^{64}$ Clarinda Rae Solberg, "Genocide in Rwanda: Recurrence Risk Model Using Two Early Warning Models", University of North Dakota: A Thesis, (2012).

${ }^{65}$ Public Sitting of International Court of Justice, Loc.Cit.

${ }^{66} \mathrm{Ibid}$.

${ }^{67}$ International Court of Justice, 2019, Application of the Convention on the Prevention and Punishment of the Crime of Genocide (The Gambia v. Myanmar), available at https://www.icjcij.org/en/case/178 accessed on Wednesday, December 25, 2019, at 19.17.

${ }^{68}$ Susana SáCouto, "Reflections on the Judgment of the International Court of Justice in Bosnia's Genocide Case against Serbia and Montenegro", American University Washington College of Law: Human Rights Brief 15, No. 1, (2007). 
case and temporarily ignore Myanmar's rebuttal. ${ }^{69}$ At present, Myanmar is not in a position to take a deadly legal blow, despite some damage to Myanmar's reputation in the international community ${ }^{70}$. The date for a decision on provisional measures has not set by the court, but it could come in January. ${ }^{71}$ The decisions of the court are binding, and the case can not bring to appeal, though it has no means of enforcement and countries have occasionally ignored them or failed to adhere adequately ${ }^{72}$. After the decision of the court release, the process may continue until it met the final judgment, and it may be in a year.

\section{a. The Role of ICJ Over Rohingya}

In the Rohingya case, ICJ plays the first role of settles international legal disputes between states. The dispute is between Gambia and Myanmar, which Gambia asked the ICJ to ask Myanmar to stop the ongoing atrocities against the Rohingya. ${ }^{73}$ The primary function of ICJ is to decide in accordance with international law such cases are submitted to it by the state as referred to Article 38 Statute international court of justice, which stated that function of the court is to decide in accordance with international law such disputes as are submitted to it, shall apply international conventions, international custom, the general principles of law recognized by civilized nations; etc. In relation to Article 38, the Genocide Convention is classified as the customary international law without a doubt. ${ }^{74}$

\section{b. Jurisdiction of ICJ Over Rohingya}

ICJ has jurisdiction over the Rohingya's case. The first reason why the international court of justice has jurisdiction upon genocide case is that the statue of the international court of justice constitutes a first part of the United Nations Charter. The international court of justice is one of the six principal organs of the United Nations. It is the principal judicial organs of the United

\footnotetext{
${ }^{69}$ James Bowen, 2015, Refugee Crisis Tests Limits of Southeast Asian Cooperation, available at https://theglobalobservatory.org/2015/05/asean-rohingya-refugees-myanmar/ accessed on Tuesday, December 31, 2019, at 10.17.

${ }^{70}$ Andrew Selth, Myanmar's Armed Forces, and the Rohingya Crisis (United States Institute of Peace: Peaceworks, 2018), 23.

${ }^{71}$ Order On Provisional Measures of International Court of Justice, 2020, Application of the Convention On the Prevention and Punishment of the Crime of Genocide (The Gambia V. Myanmar), available at https://www.icj-cij.org/files/case-related/178/178-20200123-ORD-01-00EN.pdf accessed on Wednesday, April 29, 2019, at 05.22.

72 Aloysius P. Llamzon, "Jurisdiction and Compliance in Recent Decisions of the International Court of Justice", European Journal of International Law 18, No. 5, (2007): 815-852. https://doi.org/10.1093/ejil/chm047.

73 International Court of Justice, 2019, Application of the Convention on the Prevention and Punishment of the Crime of Genocide (The Gambia v. Myanmar), Loc.Cit.

${ }^{74}$ Agnieszka Szpak, "National, Ethnic, Racial, and Religious Groups Protected against Genocide in the Jurisprudence of the ad hoc International Criminal Tribunals", The European Journal of International Law 23, No. 1, (2012): 155-173. https://doi.org/10.1093/ejil/chs002.
} 
Nations, and it is not integrated into the hierarchical structure of the other five principal organs. States that became members of the United Nations by signing and ratifying the UN Charter are ipso facto, parties to the Statute ${ }^{75}$. While the international criminal court is to be established by the treaty, these institutions will not become organs of the United Nations. ${ }^{76}$

The second reasons are the jurisdiction of the international court of justice depends on the consent of states. Article 36 (1) of the statute of the international court of justice provides it. The jurisdiction of the court covers all cases which the parties refer to it and all matters specially provided for in the Charter of the United Nations or in treaties and conventions in force. This word implies that all the parties to a dispute must agree that the case should be referred to the court.

The third reasons are the first concerns the Convention on the Prevention and Punishment of the Crime of Genocide. Article IX of the Genocide Convention 1948 stipulated that "Disputes between the Contracting Parties concerning to the interpretation, application or fulfilment of the present Convention, including those relating to the responsibility of a State for genocide or for any of the other acts enumerated in article III, shall be succumbed to the International Court of Justice at the request of any of the parties to the dispute. ${ }^{77}$ Means that the disputes of Rohingya's case are disputes between the contracting parties relating to the interpretation, applications, or fulfilment of the Convention, including those relating to the responsibility of a state for genocide will be submitted to the international court of justice at the request of any of the parties to the dispute.

In addition, Judge Elihu Lauterpacht of the ICJ stated that "the duty to 'prevent' genocide ..... Rests upon all parties" and is furthermore a duty which all parties owe to each other. ${ }^{78}$ Before the Rohingya's case arises, international court of justice had previously resolved the disputes over genocide case in the case of "application of the Convention on the prevention and punishment of the crime of genocide (Bosnia and Herzegovina $v$. Serbia and Montenegro)"79. From this case, ICJ decided that the Genocide Convention gave the ICJ jurisdiction over a suit alleging a state's perpetration of genocide. ${ }^{80}$

\footnotetext{
${ }^{75}$ Charter of the United Nations, Chapter XIV — The International Court of Justice, Article 93.

${ }^{76}$ International Criminal Court, Understanding the International Criminal Court, available at https://www.icc-cpi.int/iccdocs/PIDS/publications/UICCEng.pdf accessed on Sunday, December 15,2019 , at 14.23 .

${ }^{77}$ Machteld Boot, Genocide, Crimes Against Humanity, War Crimes: Nullum Crimen Sine Lege and the Subject Matter Jurisdiction of the International Criminal Court (Belgium: Intersentia Publishers, 2002): 62-65.

${ }^{78}$ Judge Elihu Lauterpacht, as stated by Jordan J. Paust in Jordan J. Paust, "Applicability of International Criminal Laws to Events in the Former Yugoslavia", American University International Law Review 9, No. 2\, (1994): 499-523.

${ }^{79}$ Public Sitting of International Court of Justice, Loc.Cit.

${ }^{80}$ John Quigley, Loc.Cit.
} 
In addition, about the case ${ }^{81}$ In 1993, the ICJ heard its first case regarding genocide, brought by Bosnia and Herzegovenia v. Yugoslavia. In its application, Bosnia claimed that the Serbia effort to create a "Greater Serbia" resulted in the organized bombing of Bosnian cities and the intentional targeting of its Muslim citizens. ${ }^{82}$

The Bosnian application also contends that the Serb policy of driving out innocent civilians of a different ethnic or religious group from their homes, socalled "ethnic cleansing," was practised by Yugoslav/Serbian forces in Bosnia on a measure that dwarfs anything seen in Europe since Nazi times. ${ }^{83}$ The application declared that the evidence indicates a prima facie case of genocide against Bosnia, and requested that the court take all appropriate actions in accordance with the principles of the Genocide Convention. ${ }^{84}$

In its 1994 ruling, ${ }^{85}$ The court did not issue a finding on whether genocide was being committed in Bosnia; however, it did ask the government of the Federal Republic of Yugoslavia to: ensure that any military, paramilitary or irregular armed units which may be directed or reinforced by it do not commit any acts of genocide, of conspiracy to commit genocide, of direct and public incitement to commit genocide, or of complicity in genocide, whether directed against the Muslim population of Bosnia and Herzegovina or any other national, ethnical, racial or religious group.

So, from that case, it can be concluded that the case between Gambia $v$. Myanmar is similar to the case between Bosnia and Herzegovina $v$. Yugoslavia. The terms also use similar term use in Gambia v. Myanmar case is "clearance operations," while the term used in Bosnia and Herzegovina $v$. Yugoslavia case is "ethnic cleansing". Like what already stated before, the most critical element in the genocide crime is to prove whether there is any "intent to destroy" from Myanmar. Because Rohingya is stateless, Myanmar doesn't recognize Myanmar as their citizen, and Myanmar also has no obligation to protect them. Myanmar thinks that Rohingya as one of a group that will cause damage to Myanmar.

It is hard to prove "intent to destroy" because the intention is the evidence that can not be in the hard form, this element just can be proof by the honest

\footnotetext{
81 Jeffrey S. Morton, "The International Legal Adjudication of the Crime of Genocide", ILSA Journal of International \& Comparative Law 7, (2001), 329.

${ }^{82}$ Martin Mennecke and Christian J. Tams, "The Genocide Case Before the International Court of Justice", Security and Peace 25, No. 2, (2007): 71-76. https://doi.org/10.5771/0175-274x-2007-271.

${ }^{83}$ Reports of Judgments, Advisory Opinions and Orders of International Court of Justice, 2007, Case Concerning Application of the Convention on the Prevention and Punishment of the Crime of Genocide (Bosnia and Herzegovina V. Serbia and Montenegro), available at https://www.icjcij.org/files/case-related/91/091-20070226-JUD-01-00-EN.pdf accessed on Monday, December 23,2019 , at 12.46 .

${ }^{84}$ Ibid.

${ }^{85}$ Marko Milanović, "State Responsibility for Genocide: A Follow-Up”, European Journal of International Law 18, No. 4, (2007): 669-694. https://doi.org/10.1093/ejil/chm043.
} 
statement from the person who involved ${ }^{86}$. That's why all cases regarding the genocide that bring to the ICJ never meet the element of "intent". At the end of judgment, ${ }^{87}$ the court just releases such kind of suggestion, like what the state should do in solving this kind of problem.

In such a convention, the contracting States do not have any interests of their own; they merely have, one and all, a common interest: namely, the accomplishment of those high purposes which are the raison d "être of the Convention. ${ }^{88}$ Consequently, in a convention of this type, one cannot speak of individual advantages or disadvantages to States, or of the maintenance of a perfect contractual balance between rights and duties. ${ }^{89}$ The high ideals which inspired the Convention to provide, by virtue of the collective will of the parties, the foundation and measure of all its provisions..$^{90}$ This statement was the expression of the concept of the erga omnes rights.

As explained above, the jurisdiction of the court is based on Article 36, paragraph 1, of its Statute and Article IX of the Genocide Convention. The Gambia and Myanmar are the UN Member States and parties to the Genocide Convention. Both have accepted the jurisdiction of the Court under Article IX without any reservation. As it sets out in this application, there is an existing dispute between The Gambia and Myanmar concerning the interpretation, use, and fulfilment of obligations under the Genocide Convention.

\section{Why ICJ?}

The Gambia submitted institutes proceedings against Myanmar to the International Court of Justice concerning genocide cases that happen to Rohingya Muslims in the early November 2019. The genocide is one of the grave breaches of human rights and criminal violation. Many arguments stated on the reason for the Gambia action to bring the case to ICJ, not the International Criminal Court (ICC). Is the action that taken by the Gambia is proper to bring the case to ICJ authority?

There are reasons for Gambia's action to bring the case to the ICJ. First, the problem that the Gambia asks, in this case, is not about the genocide crime itself, but the way how Myanmar has violated the Genocide Convention 1948,

\footnotetext{
${ }^{86}$ Miscellany, "Three Responses to Can There Be Genocide Without the Intent to Commit Genocide?", Journal of Genocide Research 10, No. 1, (2008), pp. 111-133. https://doi.org/10.1080/14623520701850955.

87 Andrew B. Loewenstein and Stephen A. Kostas, "Divergent Approaches to Determining Responsibility for Genocide: The Darfur Commission of Inquiry and the ICJ's Judgment in the Genocide Case", Journal of International Criminal Justice 5, No. 4, (2007): 839-857. https://doi.org/10.1093/jicj/mqm049.

${ }^{88}$ E. Hambro, The Case Law of the International Court (The Netherlands: Sijthoff International Publishing, 1977), 91.

${ }^{89}$ Michael K. Addo, International Law of Human Rights (New York: Routledge, 2016), 401.

${ }^{90}$ Loveday Hodson and Troy Lavers, Feminist Judgments in International Law (United Kingdom: Hart Publishing, 2019), 69.
} 
which already ratified by Myanmar in 1956. In the first article of the Convention, it institutes the fact that genocide acts, regardless of the presence or not of war, constitute international crimes and also commits Parties to the Convention to undertake actions to both prevent and punish the acts. So, in the Gambia perspective, Myanmar, as the contracting parties of the Convention, is failed to prevent the genocide crime that happens in their state. Also, Myanmar knows about the action, and the Tatmadaw did the action, but there is no such action taken by Myanmar to punish people who involved in that action. While, in the Myanmar side, what happened to the Rohingya is not their responsibility, even the crime happened in their state, because Myanmar doesn't recognize the existence of Rohingya as one of Myanmar citizens based on Burma Citizenship Law 1982.

Second, it also clearly stated in Article IX of the Convention. If there are any disputes between the contracting parties (Myanmar and Gambia ratified Genocide Convention 1948), it must be brought to the International Court of Justice. So, the question is, how if one of the two states is not the party of the Convention? The answer is the ICJ will have no jurisdiction upon that case because the Genocide Convention applied the principle of non-retroactive. ${ }^{91}$ Non-retroactive, or in a legal term, usually known as nullum crimen nulla poena sine lege praevia, is the prohibition of a criminal act that must exist before the criminal act itself.92 It means that the Genocide Convention (or others Convention or regulation which applied the non-retroactive principle) can't come into force before such a Convention is applied.

Third, the case cannot be brought to the ICC because Myanmar is not a signatory to the Rome Statute, and as such, a self-referral to the International Criminal Court would not be possible in this instance. Because, Rome Statute is the essential element in ICC, the statute has formulated the structure of ICC as well as the jurisdiction of ICC. Even though, if Myanmar is a signatory to the Rome Statute, the case also cannot be brought to the ICC. Because, first, what the Gambia ask in the case is state accountability which refers to Myanmar, not individual responsibility. The case regarding state accountability is a jurisdiction of ICJ, while individual responsibility being the jurisdiction of ICC. ${ }^{93}$ Second, if Gambia is bringing the case to the ICC, Gambia seems to have no guidance as to the basis for the lawsuit because the Genocide Convention is just applicable for ICJ, not ICC.

Last, the proposed of the court's jurisdiction is limited both in terms of the crimes that it may adjudicate and its relationship to the Security Council, the court's statute does include genocide as one the essential crimes that can be

\footnotetext{
${ }^{91}$ Tams, Article 14 (Jerman: Reemers Publishing Services, 2014), 311.

92 Farhad Malekian, Jurisprudence of International Criminal Justice (Cambridge Scholars Publishing, 2014), 16.

${ }^{93}$ Logan Cochrane and Abdoulie Faatty, "A Gambian Perspective on The Gambia v. Myanmar Case on the Crimes of Genocide at the ICJ", Nokoko Pod Journal, (2020): 1-22.
} 
adjudicated. ${ }^{94}$ In 1948, the United Nations wrote a definition for genocide as the attempt to destroy a national, ethnic, racial or religious group through any of the following acts: Killing members of the group, causing serious bodily or mental harm to members of the group, creating living conditions that will cause the groups' destruction (such as starvation), preventing births within the group (so its population will not grow), moving children to a separate group..$^{95}$ Besides the definition of genocide, there are two elements of genocide: ${ }^{96}$

1. Objective elements (actus reus)

a. They are killing members of the group.

b. Causing serious bodily or mental harm to members of the group.

c. It is deliberately inflicting on the group conditions of life calculated to bring about its physical destruction in whole or in part.

d. Imposing measures intended to prevent births within the group.

e. It is forcibly transferring children of the group to another group.

2. Subjective elements (mens rea)

a. It is killing members of a group.

b. It is deliberately inflicting on the group conditions of life calculated to bring about its physical destruction in whole or in part.

c. Imposing measures intended to prevent births within the group.

d. It is Forcibly transferring children of the group to another group.

Myanmar's treatment of the Rohingya includes genocide. The first defines that the Rohingyas do not have citizenship and human rights violations suffered in Myanmar, the second is political and socio-economic discrimination against Rohingya who violates their human rights, the third is violence and widespread slaughter which implies the start of the genocide in Myanmar. These four Rohingya tribes violate their human rights refugees in neighbouring countries are made unsafe because of the status of those who do not have citizenship.

State-approved violence in Myanmar creates a terrible humanitarian crisis that has escalated into the Rohingya genocide and will cause more deaths if left unchecked. Discrimination against Rohingya from 2000 to the present shows a pattern of human rights violations, which has eliminated the Rohingya's ability to live safely without hunger, illness, arbitrary detention, and physical abuse..$^{97}$ By referring to the statement, the action that was taken by the Gambia to bring the case to the ICJ is the right way to enforce international law in the global world.

\footnotetext{
${ }^{94}$ Jeffrey S. Morton, Loc.Cit.

${ }^{95}$ Mark Friedman, Genocide (Britania Raya: Heinemann Library, 2012), 4.

96 Kai Ambos, Treatise on International Criminal Law (New York: Oxford University Press, 2014), 42.

97 Linda Crossman, "Myanmar's Rohingya Refugees: The Search For Human Security", Georgetown University: A Thesis, (2014).
} 
Many Islamic countries joining the Organization for Islamic Cooperation (OIC) want to sue Myanmar, but due to the procedural lawsuit in ICJ, ${ }^{98}$ Only one country can file a case against other countries in the ICJ ${ }^{99}$ The Gambia can sue Myanmar. The Gambia filed a lawsuit in ICJ after winning the support of the OIC, which has 57 member countries, and the Gambia drove it. ${ }^{100}$ The Gambia has also asked the court to order temporary measures for Myanmar. ${ }^{101}$ Myanmar has been asked to stop its troops from taking action or contribute to the genocide crimes against the Rohingya, including murder, rape, and destruction of homes and villages. ${ }^{102}$ The Gambia also asked judges to order Myanmar to confirm evidence of atrocities. ${ }^{103}$ International Court decisions are binding and cannot be appealed. Although the court has no means of law enforcement and states sometimes ignore it or fail to comply fully. ${ }^{104}$

\section{Conclusion}

In the Rohingya case, ICJ plays the first role of settles international legal disputes between states. The dispute is between Gambia and Myanmar. For the jurisdiction, ICJ has jurisdiction over the Rohingya case. The first reason why the International Court of Justice has jurisdiction upon genocide case is that the statue of the International Court of Justice constitutes an integral part of the United Nations Charter. The second reasons are the jurisdiction of the International Court of Justice depends on the consent of states. Article 36 (1) of the statute of the International Court of Justice provides that. The third reasons are the concerns of the Convention on the Prevention and Punishment of the Crime of Genocide. Article IX of the Genocide Convention 1948 stipulated that if there is a dispute between contracting parties, they shall submit it to ICJ.

\footnotetext{
98 OIC, 2019, Resolution No. 4/46-MM on the Situation of the Muslim Community in Myanmar, available at https://www.oicoci.org/docdown/?docID=4447\&refID=1250 accessed on Thursday, December 19, 2019, at 19.17.

${ }^{99}$ UN Fact-Finding Mission, 2019, Report of the Detailed Findings.

100 OIC, 2019, Final Communiqué of the 14th Islamic Summit Conference, available at https://www.oic-oci.org/docdown/?docID=4496\&refID=1251 accessed on Thursday, December 25,2019 , at 17.16 .

1018 Note Verbale from Permanent Mission of the Republic of The Gambia to the United Nations to Permanent Mission of the Republic of the Union of Myanmar to the United Nations.

102 Amnesti International, "We Are at Breaking Point - Rohingya: Persecuted in Myanmar, Neglected in Bangladesh", Loc.Cit.

103 Ibid.

${ }^{104}$ UN Fact-Finding Mission, Loc.Cit.
} 


\section{References}

8 Note Verbale from Permanent Mission of the Republic of The Gambia to the United Nations to Permanent Mission of the Republic of the Union of Myanmar to the United Nations.

Addo, Michael K. International Law of Human Rights. New York: Routledge, 2016.

Advisory opinion of the International Court of Justice. Legal Consequences of the Construction of a Wall in the Occupied Palestinian Territory. Available online from: https://www.un.org/unispal/document/auto-insert178825/ [Accessed December 24, 2019]

Ahmed, Imtiaz. The Plight of the Stateless Rohingyas: Responses of the State, Society \& the International Community. Dhaka: The University Press Ltd, 2010.

Ambos, Kai. Treatise on International Criminal Law. New York: Oxford University Press, 2014.

Amnesti International. "We Are at Breaking Point - Rohingya: Persecuted in Myanmar, Neglected in Bangladesh". Research Report, Amnesty International Ltd, 2016.

Amnesty International UK. Myanmar: 'Damning' Video and Satellite Evidence Shows New Fires in Rohingya Villages. 2017. Available online from https://www.amnesty.org.uk/press-releases/myanmar-damning-video-andsatellite-evidence-shows-new-fires-rohingya-villages, Accessed December 23, 2019.

Amnesty International. (2004). Myanmar, The Rohingya Minority: Fundamental Rights Denied. Available online from https://www.amnesty.org/download/Documents/92000/asa160052004en.pd f, Accessed December 19, 2019.

Aziz, Aneela., Anila Kamal, "Final Proceedings of ICHRCP 2018", Conference Paper, Quaid: Azam University, 2019.

Barany, Zoltan. "The Rohingya Predicament: Why Myanmar's Army Gets Away with Ethnic Cleansing". Istitutio Affari Internazional, 2019.

Biver, Emilie. "Religious nationalism: Myanmar and the role of Buddhism in anti-Muslim narratives". Lund University (Master of Science and Department of Political Science), 2014.

Boot, Machteld. Genocide, Crimes Against Humanity, War Crimes: Nullum Crimen Sine Lege and the Subject Matter Jurisdiction of the International Criminal Court. Belgium: Intersentia Publishers, 2002.

Brown, Bartram S. "Primacy or Complementarity: Reconciling the Jurisdiction of National Courts and International Criminal Tribunals". The Yale Journal of International Law 23, No. 383, 1998.

Brown, Patrick. Preparations for Genocide and Crimes Against Humanity Against Rohingya Muslims in Rakhine State. Myanmar: Fortify Rights, 2018. 
Charter of the United Nations, Chapter XIV - The International Court of Justice, Article 93.

Cochrane, Logan., Abdoulie Faatty, "A Gambian Perspective on The Gambia v.

Myanmar Case on the Crimes of Genocide at the ICJ". NokokoPod Journal, 2020: 1-22.

Crossman, Linda. "Myanmar's Rohingya Refugees: The Search for Human Security", Georgetown University: A Thesis, 2014.

Dixon, Martin. Cases and Materials on International Law. New York: Oxford University Press, 2011.

Dussich, John P. J. "The Ongoing Genocidal Crisis of the Rohingya Minority in Myanmar". University Delhi: Journal of Victimology and Victim Justice 1, no. 1, 2018. https://doi.org/10.1177/2516606918764998.

Friedman, Mark. Genocide. Britania Raya: Heinemann Library, 2012.

D. Hambro. The Case Law of the International Court. The Netherlands: Sijthoff International Publishing, 1997.

Houck, John B. "Restatement of the Foreign Relations Law of the United States (Revised): Issues and Resolutions". The International Lawyer 20, No. 4, (1986): 1361-1390.

Ibrahim, Azeem. The Rohingyas: Inside Myanmar's Genocide. United Kingdom: C. Hurst \& Co. Publisher Ltd, 2018.

Ibrahim, Johnny. Teori dan Metodologi Penelitian Hukum Normatif. Second Edition, Malang: Bayu Media, 2008.

International Commission of Jurist. ICJ Welcomes Chance to Review the ASEAN Human Rights Commission's TOR. 2014. Available online from https://www.icj.org/icj-welcomes-chance-to-review-asean-human-rightscommissions-tor/, Accessed December 24, 2019.

International Court of Justice Press Release. (2019). Press Release No. 47. Available online from https://www.icj-cij.org/files/case-related/178/17820191111-PRE-01-00-EN.pdf, Accessed December 17, 2019.

International Court of Justice. 2019. Application of the Convention on the Prevention and Punishment of the Crime of Genocide (The Gambia $v$. Myanmar). Available online from https://www.icj-cij.org/en/case/178, Accessed December 25, 2019.

International Court of Justice. (2019). International Court of Justice Application Instituting Proceedings and Request for Provisional Measures: Republic of the Gambia V. Republic of the Union of Myanmar. Available online from https://www.icj-cij.org/files/case-related/178/178-20191111-APP-01-00EN.pdf, Accessed December 13, 2019.

International Criminal Court. Understanding the International Criminal Court. Available online from https://www.icccpi.int/iccdocs/PIDS/publications/UICCEng.pdf, Accessed December 15, 2019. 
James Bowen. Refugee Crisis Tests Limits of Southeast Asian Cooperation. Available online from

https://theglobalobservatory.org/2015/05/asean-rohingya-refugeesmyanmar/, Accessed December 31, 2019.

Kachru, Braj B. Language in Southeast Asia. Cambridge: Cambridge University Press, 2008.

Kawse Ahmed and Helal Mohiuddin. The Rohingya Crisis: Analyses, Responses, and Peacebuilding Avenues. London: The Rowman \& Littlefield Publishing Group, 2020.

Kipgen, Nehginpao. "The Rohingya Crisis: The Centrality of Identity and Citizenship". Journal of Muslim Minority Affairs 39, no. 1, 2019: 61-74, https://doi.org/10.1080/13602004.2019.1575019.

Klabbers, Jan. International Law 2nd Edition. Cambridge: Cambridge University Press, 2017.

Knuters, Simon. "Political Buddhism and the Exclusion of Rohingya in Myanmar". Uppsala Universitet (Department of Theology), 2018.

Kreb, Claus. "The International Court of Justice and the Elements of the Crime of Genocide", European Journal of International Law 18, no. 4, 2007: 619-629. https://doi.org/10.1093/ejil/chm039.

Llamzon, Aloysius P. "Jurisdiction and Compliance in Recent Decisions of the International Court of Justice". European Journal of International Law 18, no. 5, 2007: 815-852. https://doi.org/10.1093/ejil/chm047.

Loewenstein, Andrew B., Stephen A. Kostas. "Divergent Approaches to Determining Responsibility for Genocide: The Darfur Commission of Inquiry and the ICJ's Judgment in the Genocide Case". Journal of International Criminal Justice 5, no. 4, 2007: 839-857. https://doi.org/10.1093/jicj/mqm049.

Loveday Hodson and Troy Lavers. Feminist Judgments in International Law. United Kingdom: Hart Publishing, 2019.

Malekian, Farhad. The jurisprudence of International Criminal Justice. Cambridge Scholars Publishing.

Mennecke, Martin., Christian J. Tams. "The Genocide Case Before the International Court of Justice". Security and Peace 25, No. 2, 2007: 71-76. https://doi.org/10.5771/0175-274x-2007-2-71.

Milanović, Marko. "State Responsibility for Genocide: A Follow-Up", European Journal of International Law 18, no. 4, 2007: 669-694. https://doi.org/10.1093/ejil/chm043.

Miscellany. "Three Responses to Can There Be Genocide Without the Intent to Commit Genocide?". Journal of Genocide Research 10, no. 1, 2008: 111133. https://doi.org/10.1080/14623520701850955.

Mohajan, Haradhan. "History of Rakhine State and the Origin of the Rohingya Muslims", Premier University, Chittagong, Bangladesh: The Indonesian 
Journal of Southeast Asian Studies 2, no. 1, 2018: 19-46. https://doi.org/10.22146/ikat.v2i1.37391

Morton, Jeffrey S. "The International Legal Adjudication of the Crime of Genocide". ILSA Journal of International \& Comparative Law 7, 2001: 329.

OIC. (2019). Final Communiqué of the 14th Islamic Summit Conference. Available online from https://www.oicoci.org/docdown/?docID=4496\&refID=1251, Accessed December 25, 2019.

OIC. (2019). Resolution No. 4/46-MM on the Situation of the Muslim Community in Myanmar. Available online from https://www.oicoci.org/docdown/?docID=4447\& refID=1250, Accessed December 19, 2019.

Order On Provisional Measures of International Court of Justice. (2020). Application of the Convention On the Prevention and Punishment of the Crime of Genocide (The Gambia V. Myanmar). Available online from https://www.icj-cij.org/files/case-related/178/178-20200123-ORD-01-00EN.pdf, Accessed April 29, 2019.

Park, Susan. International Organisations and Global Problems: Theories and Explanations. Cambridge: Cambridge University Press, 2018.

Parveen, Ghazala. "Recent Trends in South Asian Politics: Rohingya Crisis to Nrc and Citizenship Bill in India". Kazi Nazrul University, Asansol: International Journal of Innovative Research and Advanced Studies (IJIRAS) 5, No. 10, (2018).

Paust, Jordan J. "Applicability of International Criminal Laws to Events in the Former Yugoslavia". American University International Law Review 9, No. 2, (1994): 499-523.

Philippe Sands and Pierre Klein. Bowett's Law of International Institutions. England: Thomson Reuters Ltd, 2009.

Public Sitting of International Court of Justice. (2019). Public Sitting: In the Case concerning Application of the Convention on the Prevention and Punishment of the Crime of Genocide (The Gambia v. Myanmar). Available online from: https://www.icj-cij.org/files/case-related/178/17820191211-ORA-01-00-BI.pdf, Accessed December 11, 2019.

Quigley, John. "International Court of Justice as a Forum for Genocide Cases", Case Western Reserve University: Journal of International Law 40, No. 1 , (2007): 243. https://doi.org/10.2139/ssrn.1017825.

Rahman, Md Ziaur. "Rohingya Crisis: Identity of Rohingya Muslim in Myanmar". International Community Science Association: International Research Journal of Social Science 7, No. 12, 2018.

Reports of Judgments, Advisory Opinions and Orders of International Court of Justice. (2007). Case Concerning Application of the Convention on the Prevention and Punishment of the Crime of Genocide (Bosnia and 
Herzegovina $V$. Serbia and Montenegro). Available online from: https://www.icj-cij.org/files/case-related/91/091-20070226-JUD-01-00EN.pdf, Accessed December 23, 2019.

SáCouto, Susana. "Reflections on the Judgment of the International Court of Justice in Bosnia's Genocide Case against Serbia and Montenegro". American University Washington College of Law: Human Rights Brief 15, No. 1, (2007).

Samuel C. Y. Ku and Kristina Kironska. Migration in East and Southeast Asia. Singapore: World Scientific Publishing Co. Pte. Ltd.

Selth, Andrew. Myanmar's Armed Forces and the Rohingya Crisis. United States Institute of Peace: Peaceworks, 2018.

Shaw, Malcolm N. International Law. Cambridge: Cambridge University Press, 2017.

Solberg, Clarinda Rae. "Genocide in Rwanda: Recurrence Risk Model Using Two Early Warning Models." University of North Dakota: A Thesis, (2012).

Szpak, Agnieszka. "National, Ethnic, Racial, and Religious Groups Protected against Genocide in the Jurisprudence of the ad hoc International Criminal Tribunals". The European Journal of International Law 23, No. 1, (2012): 155-173. https://doi.org/10.1093/ejil/chs002.

T. V. Paul and John A. Hall. International Order and the Future of World Politics. Cambridge: Cambridge University Press, 1999.

Tams. Article 14. Jerman: Reemers Publishing Services, 2014.

Tha, M. A. Tahir Ba. A Short History of Rohingya and Kamans of Burma. Burmese: Institute of Arakan Studies, 1963.

Ullah, A. K. M. Ahsan. "Rohingya Crisis in Myanmar: Seeking Justice for the "Stateless". Journal of Contemporary Criminal Justice 32, No. 3, (2016): 285-301.

UN Fact-Finding Mission, 2019, Report of the Detailed Findings.

UNHCR. Rohingya Emergency, 2019. Available online from https://www.unhcr.org/rohingya-emergency.html, Accessed December 23, 2019.

United Nations Treaty Collection. Chapter IV: Human Rights, Sub Chapter: Convention On the Prevention and Punishment of the Crime of Genocide. Available online from https://treaties.un.org/Pages/ViewDetails.aspx?src=TREATY\&mtdsg_no=I V-1\&chapter=4\&clang=_en, Accessed December 20, 2019.

United Nations Treaty Series. No. 1021 Convention On the Prevention and Punishment of the Crime of Genocide, adopted by The General Assembly of the United Nations On December 9 1948. Available online from https://treaties.un.org/doc/publication/unts/volume\%2078/volume-78-i1021-english.pdf, Accessed December 21, 2019. 
United States Holocaust Memorial Museum, "THEY TRIED TO KILL US ALL: Atrocity Crimes against Rohingya Muslims in Rakhine State, Myanmar", Fortify Rights: Bearing Witness Report, 2017.

Walton, Matthew J., Susan Hayward. "Contesting Buddhist Narratives: Democratization, Nationalism, and Communal Violence in Myanmar". Research Report, East-West Center, 2014.

Warzone Initiative. (2015). Rohingya Briefing Report. Available online from https://www.equalrightstrust.org/ertdocumentbank/Rohingya\%20Briefing \%20Report.pdf, Accessed December 20, 2019.

Wekke, Ismail Suardi. "Muslim Minority in Myanmar: A Case Study of Myanmar Government and Rohingya Muslims", Walisongo: Jurnal Penelitian Soaial Keagamaan 25, no. 2, 2017: 303-324. https://doi.org/10.21580/ws.25.2.2317 
